\title{
STRATEGIC \\ STRESS \\ MANAGEMENT
}

an organizational approach 
This page intentionally left blank 


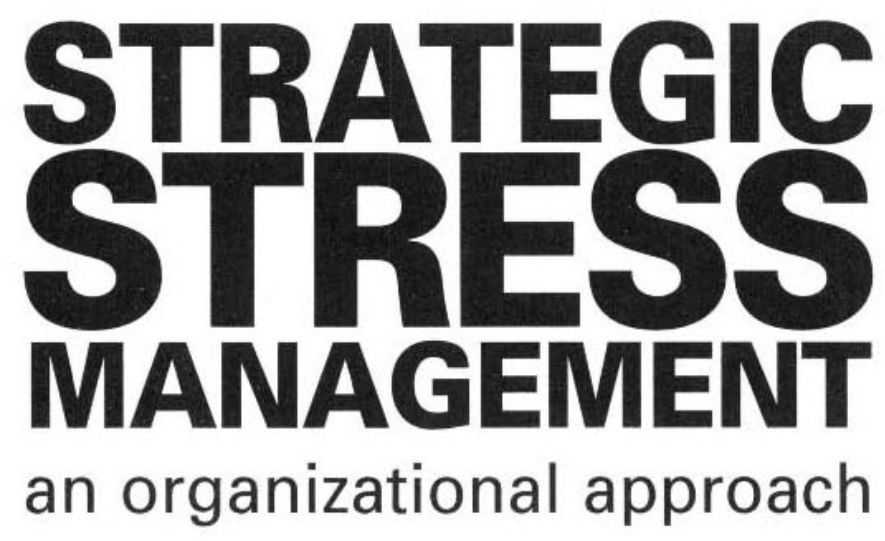

Valerie J Sutherland and

Cary L Cooper 


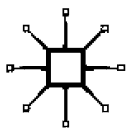

(c) Valerie J. Sutherland and Cary L. Cooper 2000

Softcover reprint of the hardcover 1st edition 2000 978-0-333-77487-8

All rights reserved. No reproduction, copy or transmission of this publication may be made without written permission.

No paragraph of this publication may be reproduced, copied or transmitted save with written permission or in accordance with the provisions of the Copyright, Designs and Patents Act 1988 , or under the terms of any licence permitting limited copying issued by the Copyright Licensing Agency, 90 Tottenham Court Road, London W1T 4LP.

Any person who does any unauthorized act in relation to this publication may be liable to criminal prosecution and civif claims for damages.

The authors have asserted their rights to be identified as the authors of this work in accordance with the Copyright, Designs and Patents Act 1988.

Published by

PALGRAVE

Houndmills, Basingstoke, Hampshire RG21 6XS and

175 Fifth Avenue, New York, N.Y. 10010

Companies and representatives throughout the world

PALGRAVE is the new global academic imprint of St. Martin's Press LLC Scholarly and Feference Division and Palgrave Publishers Ltd (formerly Macrnillan Press Ltd)

ISBN 978-1-349-41664-6 ISBN 978-0-230-50914-6 (eBook)

DOI $10.1057 / 9780230509146$

This book is printed on paper suitable for recycling and made from fully managed and sustained forest sources.

A catalogue record for this book is avallable from the British Library.

$$
\begin{array}{cccccccc}
10 & 9 & 8 & 7 & 6 & 5 & 4 & 3 \\
10 & 09 & 08 & 07 & 06 & 05 & 04 & 03
\end{array}
$$

Designed and formatted by

The Ascenders Partnership, Basingstoke 


\section{Contents}

\section{Change and the Need for Change}

Need for an Organizational Approach to Stress Management

Endorsement for Change

The Changing Face of the Work Environment

The Changing Nature of the Workplace - Consequences and Costs

Structure of the Book

2 Stress and the Law

Johnstone v. Bloomsbury Area Health Authority 29

Walker v. Northumberland County Council $\quad 29$

Lancaster v. Birmingham City Council 32

Common Law Liability - Negligence $\quad 32$

A Successful Personal Injury Claim 33

Managing Stress - Complying with Health and Safety Law 37

A Duty of Care - Employer and Employee $\quad 40$

A Policy for Stress Management $\quad 40$

Implications for Employer Liability Insurance 41

3 What is Stress?

The Origins of Stress Research 45

Stress - Myth, Reality or Whipping Boy? 57

Definitions of Stress $\quad 60$

Change as a Source of Stress $\quad 62$

4 Understanding the Nature of Stress:

Organizational Hot Spots $\quad 65$

Hot Spots: Stress in the Job Itself 66

Hot Spots: Changes to Job Role 93

Hot Spots: Changes in the Nature of Relationships at Work 97

Hot Spots: Changes in the Concept of Career 101

Hot Spots: Changes to the Organizational Structure and Climate 102

Hot Spots: The Interface Between Work and Home 105

$\begin{array}{ll}\text { Conclusion } & 107\end{array}$ 
5 Stress and New Technology 108

Computer Based Technology 111

Computer Based Monitoring 112

6 Conducting a Stress Audit $\quad 125$

The Stress Audit Process $\quad 127$

Conducting a Stress Audit: Who Does It? 134

Integrating a Stress Audit into Current Risk Assessment Processes $\quad 136$

Stress Audit Case Studies $\quad 136$

The Stress Audit - Summary 154

$\begin{array}{ll}\text { Conclusion } & 158\end{array}$

7 Options for the Management of Stress in the Workplace: an Organizational Approach

A Tripartite Model for Stress Management 162

Primary Level Stress Management Interventions 163

Secondary Level Interventions $\quad 188$

Tertiary Level Interventions 221

Conclusion 229

Appendix - Example of a Stress Log 231

References $\quad 234$

Index 256 